\title{
Good faith in the reform of insurance law
}

\author{
by Professor John Birds
}

\begin{abstract}
This article is based around a lecture delivered at the Institute of Advanced Legal Studies on 10 December 2003, with some references added and one or two other additions. The Court of Appeal decision in Drake Insurance plc v Provident Insurance plc [2003] EWCA Civ 1834, which makes some interesting, but surely controversial, statements on the duty of utmost good faith, unfortunately came too late for consideration in the lecture, but brief references are incorporated below.
\end{abstract}

G ood faith in the reform of insurance law" - there is perhaps an element of ambiguity in the title. This is not simply because I want to reserve some flexibility, but is a deliberate choice - I want to consider the process of insurance law reform and add my voice to the calls for the authorities to show good faith in examining the need for the reform of aspects of insurance law. Obviously I also want to look at some more substantive questions surrounding the concept of good faith in insurance law, but I think that my chosen title allows me to range rather further afield.

\section{PROCESS}

Anyone with even the least interest in or knowledge of insurance contract law knows that the strict doctrinal law has long been regarded as capable of operating unfairly, particularly towards the insured or policyholder. I would hasten to add that this is not of course the same thing as saying that it does always so operate. I fully accept that insurers often pay claims when strictly they are not obliged to. It would often be bad business and uneconomic for them to enquire too closely. They also do not always have it too easy. The internet provides us with a rich source of examples of some of the statements that they can be faced with. Some examples I recently found (at http:// www.carinsurances.co.uk/advice/humorous-quotes.html) are:

"The car in front hit the pedestrian but he got up so I hit him again”

"I saw a slow moving, sad faced old gentleman as he bounced off the roof of my car."

"I knew the dog was possessive about the car but I would not have asked her to drive it if I had thought there was any risk."

"I pulled away from the side of the road, glanced at my mother in law and headed over the embankment."
"My car was legally parked as it backed into the other vehicle."

Notwithstanding this, and despite recent developments that clearly have affected the operation of insurance law doctrines to some extent, the basic doctrinal law of insurance clearly recognises that the insured can act honestly or in good faith and yet be penalised by application of the doctrine of utmost good faith. Among the wealth of modern authorities concerning good faith or utmost good faith in insurance law, one unfortunately rarely finds cited what I still regard as the very apt words of McNair J in Roselodge v Castle ([1966] 2 Lloyd's Rep 113) in 1966. Having referred in particular to the classic judgment of Lord Mansfield in Carter v Boehm ((1766) 3 Burr 1905), he continued:

"This concentration upon good faith being the basis of the
duty to disclose ... if followed to its logical conclusion might
appear to lead to the result that if the proposed insured, if he
knows the fact, does not know that he ought to disclose, he
should be acquitted of a breach of good faith; but it has long
been established that if a material fact is known to the
proposer, he must disclose it whether he thought it to be
material or not." ([1966] Lloyd's Rep 113 at 129)

This surely must remain a matter for concern. Judges as well as law reform bodies have voiced the criticisms across the common law world and they go back many years. Any footnote listing the cases and extra-judicial writings where criticisms can be found would be a very lengthy one. Judicial criticisms were first picked up officially in this country by the Law Reform Committee in 1957 (Fifth Report, Cmnd 62), who made what now look like fairly modest recommendations, but they came to nought, resisted it is thought by the power of the insurance industry which stressed, as they have often done since, that they relied on their strict legal rights only if they suspected fraud. 
Twenty years later we had the more substantial project undertaken by the Law Commission. Those with long memories will recall that the impetus for the reference to the Commission was the prospect of an EC Directive seeking to harmonise core aspects of insurance contract law alongside the moves for freedom of establishment and freedom of services across the European Community. The Government needed an examination of how the principles applicable in many civil law systems could be reconciled with the way that the common law approached the question of assessing and monitoring the risk. Obviously the then state of UK law had to be examined.

The Law Commission Report of 1980 (Report No 104, Insurance Law: Non-Disclosure and Breach of Warranty, Cmnd 8064) remains the most detailed critique in this country of the duty to disclose material facts and the effect of insurance warranties, but there are a fair number of aspects of insurance law that it does not examine. It was never implemented properly, of course. Why? Probably because the Law Commission wanted the law changed across the insurance world and therefore particularly to standard commercial policies, with the exception of marine, transport and aviation insurance. The insurance industry was not prepared to countenance that. Discussions that followed the report sought to limit its effect to consumer insurances, but defining those in what was regarded as an entirely satisfactory manner was difficult. In the end the Government (of a different political persuasion than the one that had commissioned the report) agreed to what some would say was a cop out - namely the amendment of the Statements of Insurance Practice. By then, any question of the European Community seeking to deal with insurance contract law in the way previously envisaged had disappeared. I shall return later to some issues on this.

Although since then there have been no further official in the sense of Government or Government-sponsored work - looks at insurance law reform in this country, the issue does not go away. One wonders, parenthetically, whether the Department of Trade and Industry and more recently the Treasury, has actually monitored the operation of the Statements of Practice as it was promised they would when eventually the Government announced that it would not legislate on the Law Commission recommendations. Recent years have seen the production of the National Consumer Council Report, Insurance Law Reform, and more recently the British Insurance Law Association has produced its own call for reform just over a year ago (Insurance Contract Law Reform: Recommendations to the Law Commission, a Report of the Sub-Committee, September 2002). Lawyers far more distinguished than I, especially experienced senior members of the judiciary, notably Lords Justices Rix and Longmore, continue to call for reform, and their calls do not seem to me to be limited to consumer insurances (in the case of Rix LJ, his views have not just been expressed extra-judicially; see his judgment in Drake Insurance plc v Provident Insurance plc [2003] EWCA 1834). Their lectures are appended to the BILA Report.

There seems to be a real prospect now of the Law Commission looking at the question again; certainly they appear to be trying hard to persuade the Treasury to allow them to undertake at least a scoping study (to this end, a seminar was held at the Law Commission on 29 January 2004). I want to make some suggestions as to their possible agenda, but first I think that it is useful to note how the insurance scene is rather different from that of 25 years ago when the Law Commission last looked.

\section{DIFFERENCES IN THE LAST 25 YEARS}

What then are some of the differences in the insurance industry, insurance practice and indeed the operation of insurance law in the last quarter century?

First there is a rather different shape to the industry itself as a result of a large number of mergers and takeovers. Many of the household names of the last 200 years no longer exist. I do not claim that this is necessarily a significant point as regards law reform, but it is nonetheless a fact. Secondly, there seems to be a much greater volume of litigation or at least reported litigation, with the commercial disputes seeming normally to involve reinsurance. When I first studied insurance law, and indeed wrote the first edition of my book, there were probably on average two or three significant reported insurance cases every two or three years. Now they fill a specialised series and each year seems to contain a fair number of significant decisions.

The third difference is that there seems to be some evidence that freedom of services and establishment within the European Union is working to some extent and that there is increased cross-border contracting within the EU. It is certainly the case that, for example, British policyholders will effect insurance that is not just applicable within Britain. Think of the very many who take their cars to Europe each year insured under a policy issued in the United Kingdom.

Fourthly, and perhaps more importantly, we have experienced 20 years of the Insurance Ombudsman applying an increasingly consumer-orientated approach to insurance disputes and undoubtedly modifying insurance practice and the application of standard legal doctrines. The Law Commission in 1980 told us that proportionality as a modified remedy for non-disclosure would not work, but the Ombudsman has in effect made it work. Now of course the Financial Ombudsman Service has taken over the work of the Insurance Ombudsman Bureau. While there is no doubt that the FOS has continued the sterling work of the IOB, there is a fear that the pressure of work on that service, wherein insurance disputes are only a fraction of those it has to deal with, may lead to an approach that is less focused on individual disputes. 
We must also prepare for the fairly imminent prospect of the Financial Services Authority regulating the selling of general insurance and incorporating the Statements of Practice into its rules, thus moving them beyond the boundaries of "soft law". If nothing else, this must call into question the extent to which those statements need further examination to assess their applicability today. A fifth difference from 25 years ago has been the move to plain English in the drafting of proposal forms and policies. There can be no doubt that consumer policies, and some commercial policies, are much easier for the lay person to read and understand. A sixth difference is that other jurisdictions, especially Australia, have enacted substantial reform with an increasing experience that we can draw on.

My final difference and perhaps the most important one is to remind you of the substantial development that there has been in the doctrinal law, and I will spend just a few minutes outlining some of these developments.

\section{LEGAL DEVELOPMENTS}

As regards the areas of law that the Law Commission looked at, i.e. non-disclosure and breach of warranty, there have of course been some key developments. We have had clarification of the core duty of disclosure, especially in Pan Atlantic $v$ Pine Top and subsequent case law (apart from Pan Atlantic Insurance Co v Pine Top Insurance Co [1995] 1 AC 501, the list includes St Paul Fire \& Marine Insurance Co (UK) Ltd v McDonnell Dowell Constructors Ltd [1995] 2 Lloyd's Rep 116, Marc Rich \& Co AG v Portman [1997] 2 Lloyd's Rep 225, ICCI v The Royal Hotel Ltd [1998] Lloyd's Rep IR 151 and Assicurazioni Generali SpA v Arab Insurance Group [2002] EWCA Civ 1642, [2003] Lloyd's Rep IR 131) - importing an inducement requirement that did not really occur to the Commission. Of course their Lordships admitted that they were reforming the law. Even before that we had in Bank of Nova Scotia v Hellenic Mutual War Risk Association (Bermuda) Ltd, The Good Luck [1992] 1 AC 233 clarification of the effect of a breach of warranty in a manner that would require the re-examination of some critical recommendations of the Commission.

There has been important case law examining how, among other things, the basic principles of utmost good faith and disclosure apply to the common situations of coinsurance (especially New Hampshire Insurance Co v MGN Ltd [1997] LRLR 24 and Arab Bank plc v Zurich Insurance Co [1999] 1 Lloyd's Rep 262), and of course in the famous "gem stones" litigation what was ultimately a fairly ineffectual imposition of the duty of utmost good faith and disclosure on the insurer (Banque Financiere de la Cite v Westgate Insurance Co Ltd [1987] 1 Lloyd's Rep 69 (first instance), [1990] 1 QB 665, (Court of Appeal), [1991] 2 AC 249 (House of Lords)). However, if the views of Rix LJ and the other judges in the recent decision in Drake Insurance plc v Provident Insurance plc [2003] EWCA Civ 1834 are right, then the insurer's duty of utmost good faith can act to limit the remedy of avoidance. It is respectfully submitted, however, that the contrary views of the same court, but differently constituted, in Brotherton v Aseguradora Colseguros SA (No 2) [2003] EWCA Civ 705, [2003] Lloyd's Rep IR 746 are to be preferred as a matter of current law. It is notable that in Drake, the judges did not refer to this aspect of the decision in Brotherton.

We have also witnessed the introduction of some statutory protection of the insurance consumer, by virtue of the Regulations implementing the Unfair Terms Directive (SI 1999 No 2083). These may or may not apply to insurance warranties, but they clearly do apply to some terms in insurance contracts, and we should not forget that the original reference to the Law Commission asked it to examine terms and conditions other than warranties. In this context we have also had judicial recognition that the concept of the innominate term can apply in insurance contract law (Alfred McAlpine plc v BAI (Run-Off) Ltd [2000] Lloyd's Rep IR 352).

Perhaps the most important development has been the question of whether there is a continuing duty of good faith or utmost good faith in an insurance contract or at the very least what that means (See especially Black King Shipping Corp v Massie (The Litsion Pride) [1985] 1 Lloyd's Rep 437, Manifest Shipping \& Co Ltd v Uni-Polaris Insurance Co Ltd (The Star Sea) [2001] UKHL/1, [2001] 2 WLR 170, K/S MercScandia XXXXII $v$ Lloyd's Underwriters (The Mercandian Continent) [2001] EWCA Civ 1275 [2001] 2 Lloyd's Rep 563 and Agapitos $v$ Agnew (The Aegeon) [2002] EWCA Civ 247, [2002] 3 WLR 616, [2002] Lloyd's Rep IR 573). Again we would do well to remember that the decision in which that issue first properly appeared - The Litsion Pride - arose after the Law Commission Report.

All this must mean that the task of the Law Commission, if it is asked to look at insurance law again, is rather more complex than it was 25 years ago. I will shortly proceed to examine some of the issues that I suggest could be usefully and properly examined by the Commission, but first there is an important matter to return to in more detail, which is the proper meaning of good faith in the insurance context.

\section{GOOD FAITH IN INSURANCE}

What do we mean by good faith in insurance? A number of judges and commentators have talked of good faith in a manner that is, with due respect, somewhat confusing. For example, even members of the House of Lords in their speeches in The Star Sea used "good faith" rather than "utmost good faith", despite the fact the latter is what appears in section 17 of the Marine Insurance Act. Surely they are different. One can argue that "utmost" is a curious word to use in this context, and I accept that we could describe the phenomenon differently - perhaps by referring to legal good faith, but the concept is surely clear.

In my respectful view, which I would not dream of claiming to be unique, utmost good faith is concerned with 
questions of disclosure of information, and a failure to disclose leads potentially at least to a severe sanction available to the other party, because the basis of the agreement between the parties is sufficiently different from what they thought it was. Good faith is arguably a much broader concept, but with a less severe sanction, that is likely to limit the ability to exercise contractual rights. Some distinguished judges and academics think that our general contract law contains, like civil law systems generally do, a general obligation of good faith, although the weight of actual authority seems to suggest otherwise. Whatever the rights or wrongs of this, there can be no doubt that there are long-standing examples of the requirement of good faith in insurance law - for example when the insurer is exercising rights to control litigation involving its insured and when the insured acts in a way that might prejudice the insurer's subrogation rights. However, in support of my view that these are different situations, I would refer again to the view of McNair J that I cited earlier, at the same time pleading with the judges to choose their language carefully.

Fortunately, although at some expense to the various parties involved, the courts have resolved the issue I mentioned a few minutes ago - of whether there is a continuing duty of disclosure - in a satisfactory manner, in effect by saying that basically there is no such duty except when the basic cover is being altered in some way, and treating the question of fraud in making a claim as a matter for express provision or governed by general principles of policy. In this context I would respectfully draw your attention to the view, expressed extra-judicially, of Lord Justice Rix, when, in a lecture given a couple of years ago to the British Insurance Law Association, he referred to a reawakening of the underlying doctrine of good faith, which had required that remedies for breach became more thoughtful, focused, proportionate and flexible. Perhaps this comment, reflecting on the decisions in The Star Sea, The Mercandian Continent and The Aegeon, does in fact recognise that pre-contract utmost good faith is different from any contractual requirement of continuing good faith (This comment may perhaps now be seen as foreshadowing his judgment in Drake Insurance plc v Provident Insurance plc [2003] EWCA Civ 1834).

Unlike the position in some civilian jurisdictions, where there is a practice of longer-term insurance policies, we do not need a general continuing duty of disclosure. If the insurer wants protection in the context of the standard year-long indemnity policy, it can expressly provide for it (although that of course may raise issues about whether there need to be limits on what can be contractually provided).

\section{WHAT THEN NEEDS TO BE DONE?}

What then are the areas of insurance contract law that are in particular need of examination by the Law Commission?

\section{Non-disclosure and misrepresentation}

I will refer first to the fundamental questions of nondisclosure and misrepresentation. I should make it clear that I have no problem with the concept of initial disclosure in insurance. The risks have to be properly assessed. Insurance is different from most other types of contract, as Lord Mansfield recognised so many years ago. Recent case law continues to stress this peculiar quality of insurance. In the words of Lord Justice Mance in the very recent decision in Brotherton $v$ Aseguradora Colseguros SA (No 2) ([2003] EWCA Civ 705, para 24, [2003] Lloyd's Rep IR 746 at 755): "The sound philosophical basis of the duty of disclosure in an insurance context is that a true and fair agreement for the transfer of risk on an appropriate basis depends on equality of information."

The problem of course is the scope of the duty and the remedy in the event of a breach. In some respects, as I have indicated, the law is better than it was 25 years ago, but there are issues needing to be explored. Despite the developments in the common law, there can be no doubt that the Law Commission's recommendation that a proposer disclose only what a reasonable person in their position would disclose would change the law, and when a proposal form is used lead to the withering away of a pure duty of disclosure on initial application in virtually all cases. But there may still be a case for a residual duty on the proposer, if only to cover the exceptional cases where no appropriate question is asked or perhaps could reasonably be asked. A simple example, not dissimilar to ones given by the Law Commission, is the case of the householder who applies for insurance knowing that their house has been the subject of threats of arson.

Under a regime of disclosure according to the view of the reasonable insured, is there any need to worry about exactly what the inducement requirement introduced by Pan Atlantic means exactly? There are arguably issues that could still be clarified, including the exact nature of that requirement and the extent to which there is a presumption of inducement. On the other hand, the question might arise as to whether that was needed any longer.

What certainly are ripe for re-examination, I would suggest, are the remedial consequences of a non-disclosure or misrepresentation. Should the law formally enact what became the practice of the Ombudsman and allow proportionate recovery as an alternative, where appropriate, to complete avoidance? We have of course seen recent discussion of whether avoidance can be restricted by requiring that the insurer itself act in good faith, which at present is the subject of two conflicting Court of Appeal decisions (Brotherton and Drake). I always had some doubts about that development, if only because it confuses the role of utmost good faith and disclosure with the broader concept of good faith, and whether insurers' remedies can be restricted in this way surely 
cannot be decided without at least some consideration of the extent to which such a doctrine does or might apply in contract law generally. But this does not mean that a law reform agency should not seriously examine the issue.

Where there is perhaps a real problem is regarding what to do on renewal. We know that in law a renewal of an indemnity policy constitutes a new contract and that the duty of disclosure arises once more. Consumer insureds at least are warned of this on the notices that insurers send out inviting renewal. Many of us renew our household and other policies year upon year with the same insurer. This does not always require us to take any positive steps. My home insurer, which is in possession of a direct debit authority allowing it to collect its premium, sends me information just before renewal every year that makes it clear that if I am happy to carry on I need do nothing. My motor insurer requires me to contact it, but even when I do that by telephone the questions that I am asked cover a pretty limited range of information. Of course I am aware that I need to disclose to them anything that has happened within the previous year that is material, and I guess that I have a fairly good idea of what is meant by materiality, but is everyone in a similar position? I doubt it! Do people read the warnings that are fairly prominent? Do they understand them even if they do read them?

I would like here briefly to tell you a story about David Tench and the approach that he said he adopted when dealing with his insurers. David was Legal Officer of the Consumers' Association for many years including at the time that the Law Commission Report was being considered by Government. He was involved when consumer representatives were called in to Whitehall to give their views. He had decided that the best policy on renewal was to tell his insurers everything significant that had happened to him and his family during the previous year - a forerunner perhaps of the round robin missives that many people now have the habit of distributing with their Christmas cards. I remember him saying, in all seriousness, that he once told his insurers that his dog had died. When asked why, he replied that it was well know that having a dog was a deterrent to burglary and that the death must therefore be a material fact as it increased the risk of burglary. I do not imagine that David's insurer would ever have dared trying to avoid his contract of insurance for non-disclosure!

Seriously, though, there are important and difficult questions here. If the risk has changed the insurer needs to know. That is only fair to it and its other policyholders. I think that I would favour a requirement that on renewal the insured is obliged to sign and return some sort of fairly straightforward declaration, but I certainly think that it is an issue that requires detailed examination.

A more general issue in this context concerns the broad principle of utmost good faith or simply good faith as currently stated in section 17 of the 1906 Act or whatever more modern expression might be used to encapsulate it. Despite the learned views of the House of Lords in The Star Sea, I remain unconvinced that Chalmers meant to do any more than provide for an introduction to the specific disclosure etc requirements. But accepting that there is a broad principle in current law, the question arises whether it should be retained as a general principle. Should it made an implied term of the insurance contract with the consequence that on breach the innocent party would have a damages claim? This has been done in Australia and the National Consumer Council Report of 1997 and the BILA Report suggested that we should at least look at it. I have rather mixed feelings here. On the one hand I can see the attractions of such an all-embracing principle, on the other I can foresee it being raised in contexts that we can hardly imagine today, perhaps with adverse consequences. On balance I am not sure that I am comfortable with such general statements of principle, but that may be because I am a common lawyer who looks for a reasonable degree of certainty!

\section{CO-INSURANCES}

Another area which seems to be ripe for detailed examination is that of co-insurance. Although, as I indicated earlier, there has been case law clarifying the position in respect of utmost good faith and the effect of breaches of warranty or condition and wilful misconduct in cases where more than one person is insured under the same policy, there are questions as to whether or not the correct or the fair result has been reached in all cases. We should not forget that co-insurance is a remarkably common phenomenon, whether it involves the spouses who insure their property together or the insurance jointly effected by, for example, mortgagor and mortgagee; there are many other examples that could be given.

The basic position seems to be that if the insurance is properly joint, that is joint insurance of property jointly owned, then an innocent co-insured is affected by the action or inaction of the guilty co-insured. The rationale for this has been challenged in New Zealand case law (see for example Maulder v National Insurance Co of New Zealand [1993] NZLR 351), and there is at least an issue as to whether or not the principle operates fairly. For example, is it right that the wholly innocent partner of the coinsured who burns down their jointly owned house receives nothing? If it were felt that they should receive something, how much should that be?

On the other hand, deciding in effect that composite insurances amount to bundles of separate contracts, as seems to be the result of decisions like $M G N_{V} \mathrm{New}$ Hampshire and Arab Bank v Zurich, can sometimes also lead to curious results, certainly in a situation where one coinsured commits fraud. Of course insurers can protect themselves to some extent against consequences that they do not like by drafting, but I am not convinced that this is 
a complete answer to the question of whether or not the basic legal position merits reflection.

\section{TERMS AND CONDITIONS}

As I have already said, and as I am sure you recall anyway, the second major aspect of insurance law that the Law Commission examined was the law of insurance warranties. Probably the critical recommendations here were those to abolish the basis of the contract clause, which may still be found in commercial proposal forms, and to require a causal link between breach and loss before a claim could be defeated. It seems almost self-evident that the law should provide along those lines, and it might help to avoid some of the contortionist reasoning that the courts seemingly felt had to be adopted in cases like Printpak v AGF ([1999] Lloyd's Rep IR 542) and Kler Knitwear v Lombard ([2000] Lloyd's Rep IR 47), so that the insured was not prejudiced by what in both cases were breaches of warranty that were unrelated to the claim. If the reason for the insurers' view in those cases was a suspicion of fraud or some other wrongdoing, then they should have had to prove it.

However, there are other issues that I would argue should now be looked at. I was never very happy that the Law Commission did not go beyond warranties and look at other terms, especially those that might be called "conditions" but which serve the same risk controlling function as warranties. Their rather cavalier statement that if insurers tried to evade a new warranty law by using other means, someone would step in and regulate them seemed to me over-optimistic at the time. In this context it would be worthwhile to examine the impact of applying the innominate term concept to insurance.

Another issue would be the relationship between insurance terms and the Unfair Terms Regulations. Let me hasten to say here that I have no problem with the concept of a warranty as a device that limits the risk to which the insurer is subject. If an insured clearly knows that they should have a properly working security system, for example, then I have no sympathy with them if they have not and suffer a causally-related loss. So I would not wish warranties and other terms of that sort to be open to assessment on the basis of fairness, as opposed to intelligibility, not indeed do I think that they in fact are. But others think differently and this is clearly therefore a matter that deserves further consideration.

\section{INSURER'S FAILURE TO PAY}

There is one other substantive issue that I want to discuss. In a sense it is unrelated to those I have already mentioned, which all in some way or another affect the risk that the insurer is subject to under the contract, but in another sense it is related because it raises the issue of the good faith of the insurer. This is good faith in its general lack of an effective remedy for the insured when the insurer for no good reason delays unduly in settling a claim. You will recall the decision in Sprung v Royal Insurance (UK) Ltd ([1997] CLC 70) and the earlier authorities that rule out a damages remedy for somewhat arcane and obscure reasons (contrast the approach of the Canadian Supreme Court in Whiten v Pilot Insurance Company 2002 SCC 18).

This could be of course be dealt with by a general statutory obligation on the insurer as well as the insured to act in good faith, but at the very least it needs examination on its own. But we should also note that there might be a statutory remedy under section 150 of the Financial Services and Markets Act 2000 when the FSA Code on general insurance selling comes into force.

\section{OTHER ISSUES}

In the items I have outlined above, I have tried to identify what I think are the key issues for insurance law reform. There are others that I will not consider in detail, for example issues of agency (the notorious rule in Newsholme Bros $v$ Road Transport \& General Ins Co ([1929] 2 $\mathrm{KB} 356)$ ) and of subrogation that were considered in the National Consumer Council Report. And I am sure that other people would think of yet more (For example the meaning of insurable interest, especially following the Court of Appeal decision in Feasey v Sun Life Assurance Co of Canada [2003] EWCA Civ 885, [2003] Lloyd's Rep IR 637). This seems to indicate to me that any reference to the Law Commission should, at least initially, be a fairly open-ended one.

\section{To whom would this all apply?}

I have already said that the Law Commission was adamant that their proposals should apply across the board, with the exception only of marine, aviation and transport insurance. In retrospect this looked like a mistake, and there is an argument that any reform should only apply to individual consumers and small businesses (those perhaps within the jurisdiction of the Financial Ombudsman Scheme), on the ground that bigger businesses can protect themselves with professional advice. On the other hand, as I have said I am pretty sure that the distinguished judges calling for reform did not confine their remarks in this way. My own view is a pragmatic one at this stage. If a limited reform is much more likely to be acceptable, then I would go for that on the grounds that it is better than nothing.

\section{CONCLUSION}

I hope that what I have said has at the very least stimulated you to think further. I am conscious that I have probably raised more questions than given firm answers, but that is because I am not sure that I know all the answers. I do think that we would all benefit from a modern insurance code concerning the most fundamental 
aspects of insurance contract law. But we must be wary that any reform does not provide a means for insurers to introduce terms and conditions "by the back door". Whatever the outcome might be, I would like to add my voice to the more authoritative ones asking for the Government to show good faith by agreeing to a review of insurance contract law.

I should add that I do not think that most of the various proposals for reform that have been made over the past 25 years are anti-insurance. There may be some who would say that insurers should pay up every time, but I am not one of those. I think that there is a perception problem, though, and that a common feeling is that "they have taken my money, so now I want some of it back". There is a "story" that I have come across (at http://www.insurance. lt/index.php/en/12509/) that quite nicely illustrates what seems to be this perception. Bear in mind that it is from the USA.

"Mr John Mumford III was a rich old man dying from a rare disease. On his deathbed, he called for his insurance agent, doctor and preacher: "I trusted each of you my entire life. Now I want to give each of you \$30,000 cash in an envelope to put in my grave. I want to take it with me." At the funeral, each one placed their envelope on top of the man, then he was laid to rest. On the way back from the funeral, in the limo, the doctor confessed, "I must tell you gentlemen, I only put \$20,000 on top of Mr Mumford. I wanted to buy this new machine that would enable me to diagnose the rare disease he had and save others. It's what he would have wanted". Then the preacher said: "I have to confess too. I only put \$10,000 on top of Mr Mumford. We needed that money to help more homeless, and it's also what Mr Mumford would have wanted". The insurance agent was angry with both the men, and said: "I can't believe both of you, stealing from a dead man. I wrote Mr Mumford a cheque for the full $\$ 30,000 !$

It seems to me that a balanced reform that changes the law, but not really the practice, of insurance could be effected in a way that presented the industry in a better light than this.

Professor John Birds

University of Sheffield 